Article

\title{
An Overview of Construction Occupational Accidents in Hong Kong: A Recent Trend and Future Perspectives
}

\author{
Muhammad Shafique ${ }^{1, *(1)}$ and Muhammad Rafiq ${ }^{2,3}$ \\ 1 Department of Architecture and Civil Engineering, City University of Hong Kong, Hong Kong, China \\ 2 Department of Electrical Engineering, University of Engineering and Technology, Taxila 47050, Pakistan; \\ muhammad.rafiq@uettaxila.edu.pk \\ 3 School of Electrical and Electronic Engineering, North Electric Power University, Beijing 102206, China \\ * Correspondence: m.shafique@my.cityu.edu.hk
}

Received: 29 April 2019; Accepted: 17 May 2019; Published: 20 May 2019

\begin{abstract}
The construction industry is infamous for a high number of fatalities around the world. The Hong Kong construction industry is also one of the most hazardous industries for worker's safety compared to all other industries. This paper presents a current trend of occupational injuries among Hong Kong construction workers. Yearly reports of the labour department of Hong Kong were evaluated in this study. A statistical analysis of incidence rates (IRs) and mortality rates (MRs) was performed to evaluate each accident type. Moreover, analysis of variance (ANOVA) was performed to find out the relationship between IRs and MRs of individual accident type. From the analysis, "Slip, trip or fall on the same level" caused the higher number of occupational injuries while "fall of the person from height" caused the higher number of occupational fatalities from 2011 to 2017. Finally, the future perspectives of effective safety management system incorporated with advance technologies in the construction industry are highlighted in this study.
\end{abstract}

Keywords: occupation injuries; construction workers; fatalities; ANOVA; safety management system; future perspectives

\section{Introduction}

The world's population has been rapidly increasing during the past few decades [1,2]. To accommodate this immense population within the available land, the construction of taller buildings is gaining more attention. This is due to taller buildings having the ability to accommodate more people on smaller land. However, the construction of high-rise buildings poses severe threats and safety issues to the construction workers around the world [3-5]. Consequently, construction workers are more likely to face a number of difficulties such as severe weather conditions as well as safety issues at higher elevations (falling from height, struck by objects at the site, etc.). These may cause severe occupational injuries among construction workers around the world [4,6,7].

Higher mortality rates among construction workers still remain a global major concern for policymakers. Among all major industries, construction workers face the highest number of the risks of occupational injuries and illnesses around the world [8-10]. In addition, in 2017 of the overall industrial fatal accidents in Japan, the United Kingdom, the United States, and Hong Kong, 20\% of these accidents were related to construction activities [11-14]. Similar studies by Fabiano et al. [15] and Macedo [16] revealed the construction industry as one of the most fatal industries in Italy and Portugal respectively. Another study of Jackson and Loomis [17] evaluated the fatality trends in North Carolina construction industry from 1978 to 1994. A recent study of Wanjo et al. [18] for the Korean construction 
industry was conducted to evaluate occupational injuries among workers from 2011 to 2015. Results of this study indicated that the fall of a person from height was the leading cause of fatality in the Korean construction industry. Notably, in Hong Kong, 76\% of industrial fatalities in year 2017 took place only in the construction industry [12].

On the other hand, the Workplace Safety and Health Institute (WSH)'s report states that the number of fatality from occupational accidents in Asia was higher from all five regions [19]. Besides, the WSH's report also identified that construction industry as one of the most dangerous industries in the world. A comprehensive study by Sunindijo and Zou [8] revealed that in several countries "construction industry accidents and fatality rates were found to be higher than other industries." Usually, most of the accidents at a construction site are due to the unawareness of the safety precautions [20,21]. In addition, the construction projects are characterized as multifarious because of their difficult sites and tough working conditions. They are also described as temporary projects [9]. This is due to the fact that most of the construction workers are hired on a temporary basis. As the construction workers spend a lot of time at high-risk construction sites, this leads to higher fatality rates among construction workers $[4,21]$. Accidents in the construction industry are frequently due to dangerous sites, and may lead to serious injuries or fatalities [10,22]. In Hong Kong, construction accidents are more prevalent because of low safety measures and unskilled labor. This leads to higher fatality rates as well as serious injuries in the construction industry. These catastrophic figures stress greatly the need for a precise and effective safety management system (SMS) in the construction industry.

A safety management system (SMS) was legally imposed in Hong Kong in 1991. The main purposes of the SMS were to mitigate workplace accidents, injuries and promote as safer environment in the construction industry. Despite the adoption of the SMS, construction accidents have still been increasing in the past few years not only in Hong Kong but all around the world. Figure 1 below indicated how accidents in the construction industry were increasing and continuously reported around the world. Apart from the developing economies, the construction industry is also indicated as precarious in developed economies due to higher fatal accidents [19,23,24]. The number of fatality rate in the Hong Kong construction industry in 2017 was noted highest among all the developed economies [19].

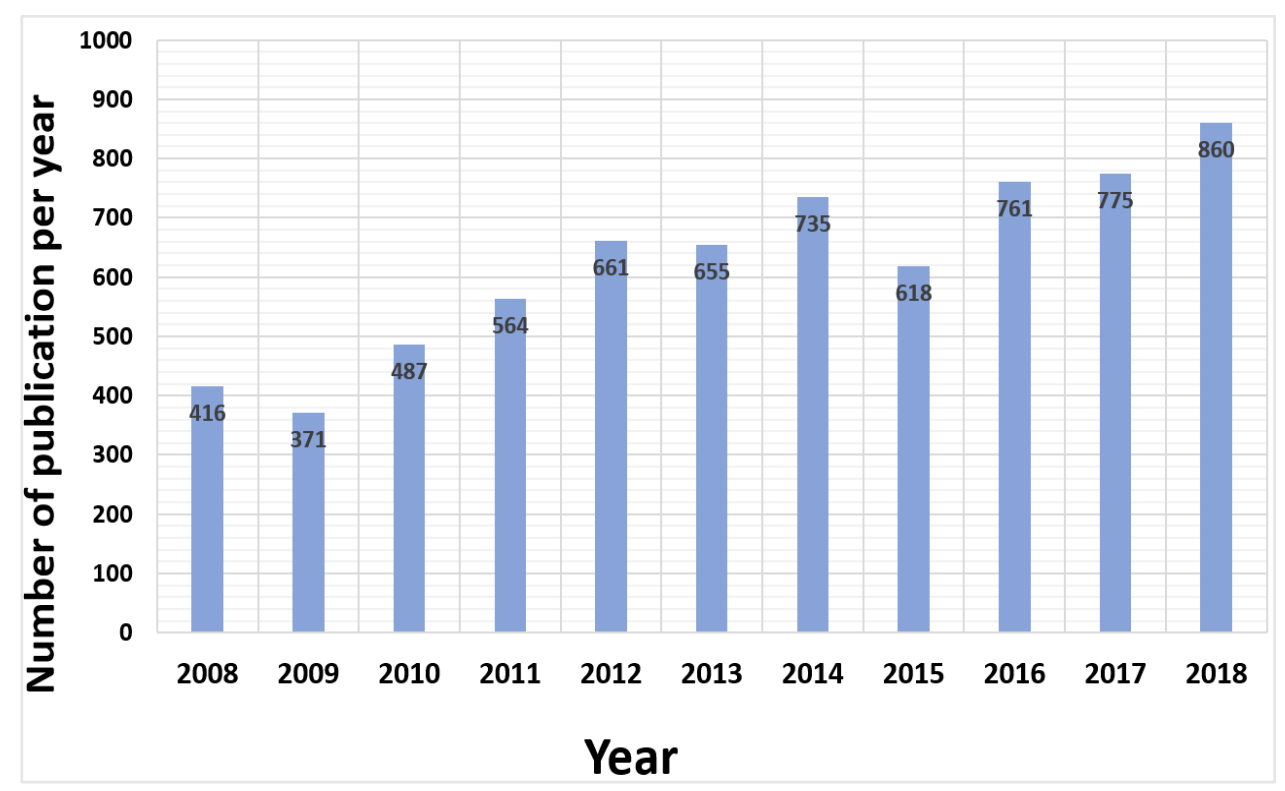

Figure 1. Distribution of global studies on construction accidents from 2008-2018. [Scopus databases].

Accident analysis is a key factor in SMS which significantly helps to identify the main factors which may cause the fatal accidents. It also helps to develop an effective accident prevention network to reduce fatal accidents in the construction industry. Research results revealed that there was a miraculous 
decline in construction accidents rate immediately after the adaptation of SMS in Hong Kong. However, the decreasing accident rate has slackened recently [25-27]. Therefore, it is necessary to evaluate accident types which cause more fatalities in the Hong Kong construction industry. This process not only helps to implement SMS successfully but also to achieve sustainable safety in the construction industry. To evaluate this more comprehensively, this study was developed to evaluate the recent occupational accidents trends in the Hong Kong construction industry. The main aim of this study was to identify the major accident types which are causing a higher number of occupation accidents (injuries and fatalities) in Hong Kong construction industry from 2011 to 2017. In addition, this study investigates the occupational fatality and injury rate associated with accident type of Hong Kong construction industry. Moreover, this study will provide a future perspective of sustainable and effective SMS to reduce construction fatal accidents in Hong Kong. This paper could play an important role to establish an effective network to reduce fatal accidents in Hong Kong.

\section{Research Significance and Motivation}

Several studies $[23,28,29]$ were conducted to evaluate construction safety management in Hong Kong. These studies have evaluated various factors such as age, accident types, etc. in repair and maintenance work. A recent study of Chaing et al. [28] evaluated the fatal accidents in the Hong Kong construction industry through data of the past 20 years. However, there is a lack of studies which assess the fatalities with respect to various accidents type and their relationships with each other particularity with recent available data in Hong Kong. This study fills this gap by mainly focusing on the major accident types which cause more occupational injuries and fatalities among the construction workers in Hong Kong. Moreover, accidents type and their relationships with each other were evaluated with the help of one-way analysis of variance (ANOVA) through the study period. Lastly, this study will identify the potential contributory factors for successful implementation of SMS in the Hong Kong construction industry. Besides, it also suggests the future perspective of advanced technologies to reduce construction accident (falls and struck by an object) in Hong Kong.

\section{Methodology}

\subsection{Data Extraction}

The overall records of accidents data in the Hong Kong's construction industry during the period of 2011 to 2017 have been collected and systematically analyzed to evaluate the accident types, and risks. In addition, the more attention was given to evaluate the main factors which caused the accidents among workers of the construction industry. In this research analysis, yearly records of industrial accidents were collected from the Labour Department of Hong Kong [30]. In Hong Kong, the Labour Department is the department which is mainly responsible for the improvement and development of laws and regulations for safety in Hong Kong industries. This is also handled by policies related to labour safety and security at the workplace as well as safety standards and occupational safety at site and health in the whole country. The Labour Department is continuously gathering all data related to occupational injuries and fatalities at the workplace. Then, yearly accidents data are published at the Labour Department portal of all industries. It includes occupational injuries, fatalities, and type of accidents for various industries. The records in the Labour Department reports include information about the workforce and accidents information from 2011 to 2017. The authors have carefully investigated all the reports to evaluate accident types and fatality rate in the Hong Kong construction industry workers. The overall information regarding the fatal accidents types and fatality rate were collected through the Labour Department from 2011 to 2017. Through this, the recent trends of industrial construction accidents were found and investigated. 


\subsection{Data Collection and Analysis}

Data were collected and analyzed to find out the recent patterns of fatal accidents among Hong Kong construction workers. In addition, the main accident types of injury and fatality were identified among the construction workers. The total injuries in this study include the overall injuries (fatal-non fatal injuries) among several groups. Fatal accident included the total number of fatalities in the construction industry. The study variable (accidents type) was used to evaluate occupational injuries in construction workers. The main idea was to evaluate the accident type which caused more accidents in the Hong Kong construction industry. Through the overall occupational accidents records, there were 25,182 occupational injuries and 140 fatalities from 2011 to 2017.

The occupational injury rates (incident rates and mortality rates) were measured to evaluate the occupational accidents trends in the Hong Kong construction industry. This study follows the methodology of Jo et al. [18] and Chaoi et al. [24], where they have utilized the incidence rates (IRs) and mortality rates (MRs) to evaluate construction fatal accident trends in China, South Korea and the U.S. For this study, the incidence rate was calculated as the total number of injuries per 100 workers engaged in the construction industry. Moreover, the mortality rates were evaluated on the number of fatalities per 100,000 workers with respect to accident type through the analysis period.

The IRs and MRs were obtained by measuring the number of workers selected in a particular year as the denominator (see the below equation).

$$
\begin{gathered}
\text { Incidence Rates }(\text { IRs })=\frac{\text { Total number of occupational injuries }}{\text { Total number of workers }} \times 100 \\
\text { Mortality Rates }(\text { MRs })=\frac{\text { Total number of occupational fatalities }}{\text { Total number of workers }} \times 10^{5}
\end{gathered}
$$

The data collected from Hong Kong construction workers were compiled to a database in Microsoft Excel 2017 (Microsoft Corporation, Redmond, WA, USA), through which several analysis on construction workforce and fatal accidents were conducted during 2011-2017. In addition, for the descriptive analysis, the mean of each accident type was calculated throughout the study period. To analyze data on each accident's type and their relationship were compared by using the ANOVA tests in this study. Moreover, the comparisons between individual categories were performed through the post hoc tests. P-values below 0.05 were acknowledged as statistically significant. The authors used the SPSS (Statistical Package for Social Sciences) version 21 for statically analysis in this study. Finally, the authors evaluated the main causes and trends of occupational injuries among the construction workers in Hong Kong from 2011 to 2017.

\section{Results}

\subsection{Overview of Workers and Occupational Injuries}

The numbers of construction workers and occupational accident details are mentioned in Table 1. It also describes an overall increasing trend in the number of construction workers in Hong Kong since 2011. During the analysis, the mean numbers of construction workers were around 88,229, while the mean occupational injuries and fatalities were found to be around 3597 and 20 respectively. The total numbers of occupational injuries in Hong Kong were significantly increased yearly. However, there was a mixed trend in incident rates and mortality rates throughout the analysis period. On the other hand, both mortality rates (9.27), as well as incidence rate (3.6), were shown to be significantly lower in 2016. However, the incidence and mortality rate were increased in 2017 which required a huge attention to tackle this situation for human well-being at the workplace. 
Table 1. The details of construction workers and occupational injuries among Hong Kong construction workers from 2011 to 2017.

\begin{tabular}{cccccc}
\hline \multirow{2}{*}{ Year } & \multirow{2}{*}{ Workers (n) } & \multicolumn{2}{c}{$\begin{array}{c}\text { Occupational } \\
\text { Injuries (OIs) }\end{array}$} & \multicolumn{2}{c}{$\begin{array}{c}\text { Fatal Occupational } \\
\text { Injuries (FOIs) }\end{array}$} \\
\cline { 3 - 6 } & & Number (n) & IRs & Number (n) & MRs \\
\hline 2011 & 62,635 & 3188 & 5.1 & 23 & 36.7 \\
\hline 2012 & 71,295 & 3252 & 4.6 & 24 & 33.7 \\
\hline 2013 & 79,303 & 3332 & 4.2 & 22 & 27.7 \\
\hline 2014 & 82,795 & 3573 & 4.3 & 20 & 24.2 \\
\hline 2015 & 95,103 & 3863 & 4.1 & 19 & 19.9 \\
\hline 2016 & 107,799 & 3860 & 3.6 & 10 & 9.27 \\
\hline 2017 & 118,674 & 4114 & 3.5 & 22 & 18.5 \\
\hline Mean & 88,229 & 3597 & - & 20 & - \\
\hline
\end{tabular}

Table 2 indicates the overview of occupational injuries with respect to the accident type from 2011 to 2017. The total numbers of occupational injuries (OIs) were increased over the year with several accident types such as fall of a person from height and slip, trip or fall on the same level, injured while lifting or carrying as shown in Table 2. Overall data has shown a fluctuation, increasing and decreasing in fatal occupational injuries (FOIs) over the analysis period. From the 2011 to 2017 data analysis, there was a mixed trend in OIs and FOIs in the Hong Kong construction workers. However, in 2016, there were a lower number of FOIs and OIs as compared to all other years. Result analysis also showed there was a decreasing OIs trend with an increasing number of workers of construction workers throughout the analysis period. With respect to the accident types, the higher number of FOIs and IOs occurred in "Fall of person from height" through the analysis period. Moreover, the most dangerous accidents types which cause more OIs were slip, trip or fall on the same level and injured while lifting or carrying. On the other hand, in the second accident type most more FOIs were striking against or struck by a moving object, contact with electricity or electric discharge and Struck by falling object. Results of the analysis showed an increasing trend in OIs from 2011 to 2017 among construction workers.

Table 2. The overview of the occupational injuries (OIs) and fatal occupational injuries (FOIs) among Hong Kong construction workers during the study period.

\begin{tabular}{|c|c|c|c|c|c|c|c|c|c|c|c|c|c|c|}
\hline \multirow{2}{*}{ Accidents Types } & \multicolumn{7}{|c|}{ OIs } & \multicolumn{7}{|c|}{ FOIs } \\
\hline & 2011 & 2012 & 2013 & 2014 & 2015 & 2016 & 2017 & 2011 & 2012 & 2013 & 2014 & 2015 & 2016 & 2017 \\
\hline Fall of person from height & 390 & 429 & 439 & 374 & 380 & 351 & 381 & 10 & 12 & 15 & 7 & 9 & 7 & 9 \\
\hline $\begin{array}{c}\text { Striking against fixed or } \\
\text { stationary object }\end{array}$ & 280 & 295 & 311 & 390 & 382 & 392 & 447 & 0 & 1 & 0 & 0 & 0 & 0 & 0 \\
\hline $\begin{array}{c}\text { Contact with electricity or } \\
\text { electric discharge }\end{array}$ & 6 & 17 & 10 & 12 & 8 & 7 & 9 & 2 & 7 & 0 & 2 & 3 & 2 & 0 \\
\hline $\begin{array}{c}\text { Injured while lifting } \\
\text { or carrying }\end{array}$ & 606 & 525 & 490 & 453 & 677 & 626 & 724 & 0 & 0 & 0 & 0 & 0 & 0 & 0 \\
\hline Trapped in or between objects & 106 & 114 & 137 & 205 & 160 & 158 & 147 & 1 & 1 & 0 & 2 & 1 & 0 & 3 \\
\hline
\end{tabular}

* Others: includes all accidents types other than those mentioned above in occupational safety and health statics, Labour department of Hong Kong. 


\subsection{Overview of Incidence and Mortality Rates}

The analysis overview of IRs and MRs with respect to accident types are shown in Table 3. A number of accident types were studied from the occupational report and specific data of accident types were collected throughout the analysis period. The main accidents types which caused more occupational injuries are shown in Table 3. There were around 9 categories were selected which were significant with respect to occupational injuries. From the analysis, the highest indices of IRs were found from "slip, trip or fall on same level" from 2011 to 2017 in the Hong Kong construction industry. The second higher IRs involved in "Injured while lifting or carrying" followed by "Striking against or struck by moving object" in construction workers from 2011 to 2017. On the other hand, "fall of person from height" was most significant accident type which contributed in higher mortality rates (MRs) throughout the study period. Moreover, the second accident type was "Striking against or struck by moving object" with respect to MRs which have higher fatalities in each year among construction workers. Meanwhile, the MRs involved in "Contact with electricity or electric discharge" decreased each year and found to be 0 in 2017. A similar decreasing trend was found in the "struck by falling object" throughout the analysis period. The IRs of "fall of person from height" and "striking against object or vehicles" was decreased by each year till 2017. Other accident types such as "Striking against fixed or stationary object", "Trapped in or between objects" and "others" indicated the mix trends in IRs and MRs during the study period as shown in Table 3.

Table 3. The overview of incidence rates (IRs) and mortality rates (MRs) correspond to accident type from 2011 to 2017.

\begin{tabular}{|c|c|c|c|c|c|c|c|c|c|c|c|c|c|c|}
\hline Accidents Types & \multicolumn{7}{|c|}{ IRs } & \multicolumn{7}{|c|}{ MRs } \\
\hline Fall of person from height & 0.62 & 0.60 & 0.55 & 0.45 & 0.40 & 0.33 & 0.32 & 15.97 & 16.83 & 18.91 & 8.45 & 9.46 & 6.49 & 7.58 \\
\hline $\begin{array}{l}\text { Striking against fixed or } \\
\text { stationary object }\end{array}$ & 0.45 & 0.41 & 0.39 & 0.47 & 0.40 & 0.36 & 0.38 & 0 & 1.40 & 0 & 0 & 0 & 0 & 0 \\
\hline $\begin{array}{l}\text { Contact with electricity or } \\
\text { electric discharge }\end{array}$ & 0.01 & 0.02 & 0.01 & 0.01 & 0.01 & 0.01 & 0.01 & 3.19 & 9.82 & 0 & 2.42 & 3.15 & 1.86 & 0 \\
\hline $\begin{array}{l}\text { Injured while lifting } \\
\text { or carrying }\end{array}$ & 0.97 & 0.74 & 0.62 & 0.55 & 0.71 & 0.58 & 0.61 & 0 & 0 & 0 & 0 & 0 & 0 & 0 \\
\hline
\end{tabular}

* Others: includes all accidents types other than above mentioned in occupational safety and health statics,

Labour department of Hong Kong.

\subsection{Comparison of Mean of Incidence Rates (IRs) and Mortality Rates (MRs) of Each Accident Type}

Figure 2 below shows the mean ratio computed when comparing the IRs and MRs each accident type from 2011-2017. From the analysis, it was indicated that the highest mean MRs accident type "fall of person from height" was (11.96). Followed by the Mean MRs of "contact with electricity or electric discharge" and "struck by falling object" respectively. On the other hand, the mean IRs of most of the accident types were lower than the mean MRs value. However, the results indicated the greater value of means of IRs of "strip, trip or fall from same level", "striking against fixed or stationary object" and "injured while lifting or carrying" accident types when compared with the mean MRs from 2011-2017. This indicated that there is a significant difference between IRs and MRs of each accident type from 2011-2017 among Hong Kong construction workers. 


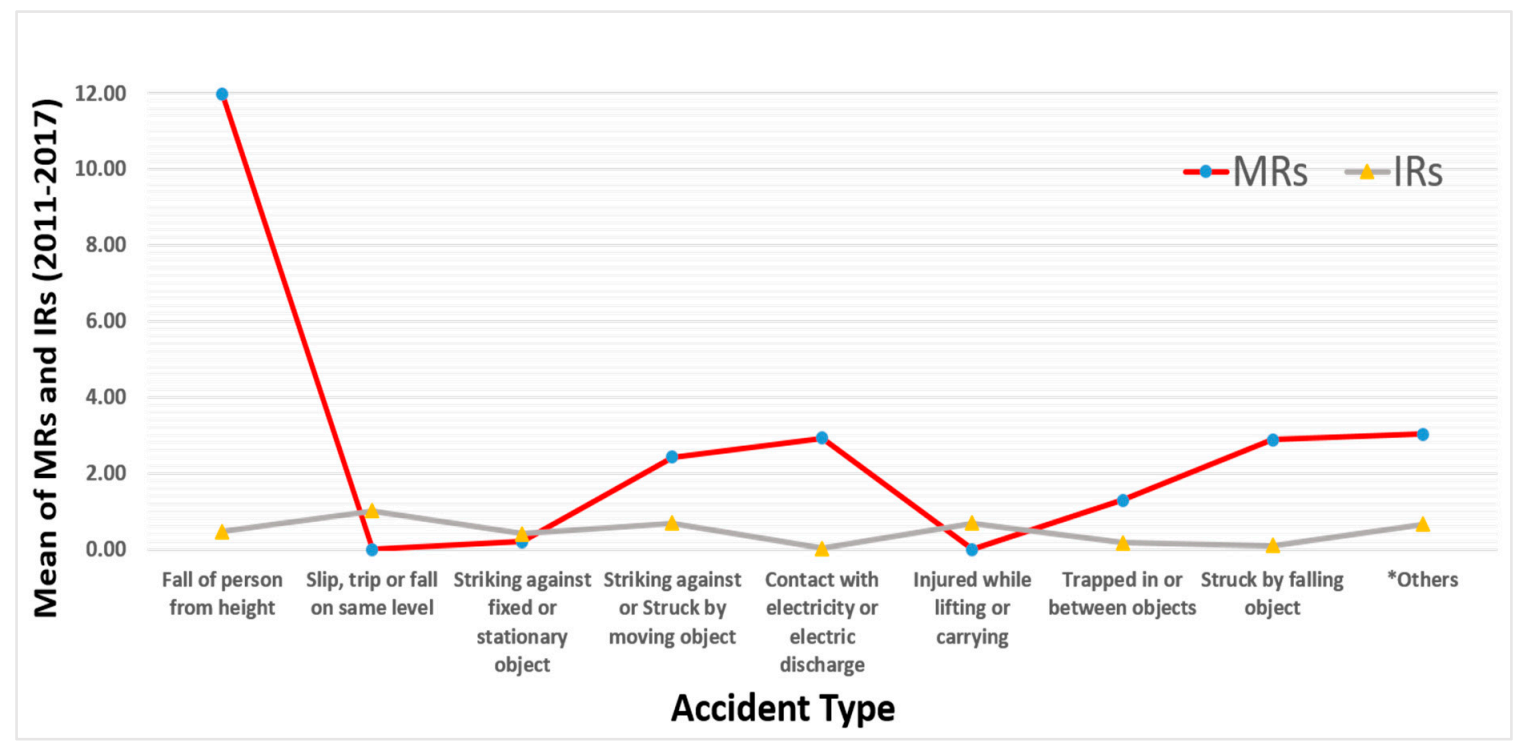

Figure 2. Mean of incidence rates (IRs) and mortality rates (MRs) of each accident type during the whole analysis period. (*Others: includes all accidents types other than mentioned above in occupational safety and health statics, Labour department of Hong Kong).

\subsection{One-Way Analysis of Variance (ANOVA)}

To compare accident type with each other and their effects for incidence and mortality rates were evaluated during the analysis. For this purpose, the ANOVA test was applied and results were compared with each other in this study as shown in Tables 4 and 5. The results indicated a momentous difference in IRs on accident type at the $\mathrm{p}<0.001$ level. The post-hoc comparison based on accident types $(\mathrm{F}=87.566, \mathrm{p}<0.001)$ of the construction worker's fatality was significantly different with each other in each year during the analysis period. In addition, it was found that the IRs of "Slip, trip or fall on same level" (mean $=1.004$ and standard deviation $(\mathrm{SD})=0.0489$ ) were indicated the significant effect with than all other accident type during the analysis. On the other hand, the IRs of "fall of person from height" (mean $=0.468, \mathrm{SD}=0.126$ ) indicated the significant result with all other accident types expect "Striking against fixed or stationary object" throughout the study period. During the analysis, all other accident types have shown mixed trends in the comparison study.

Table 4. One-way analysis of variance (ANOVA) results based on incidence rates (IRs).

\begin{tabular}{|c|c|c|c|c|c|c|c|c|c|c|c|}
\hline & \multicolumn{11}{|c|}{ Accidents Type $(\mathrm{F}=87.566, \mathrm{p}<0.001)$} \\
\hline & Accident Type & $\begin{array}{l}\text { Mean } \\
(\mathrm{SD} \pm)\end{array}$ & 1 & 2 & 3 & 4 & 5 & 6 & 7 & 8 & 9 \\
\hline 1 & $\begin{array}{l}\text { Fall of person } \\
\text { from height }\end{array}$ & $\begin{array}{c}0.468 \\
(0.126)\end{array}$ & & $* * *$ & ns & $* * *$ & $* * *$ & *** & $* * *$ & $* * *$ & *** \\
\hline 2 & $\begin{array}{l}\text { Slip, trip or fall } \\
\text { on same level }\end{array}$ & $\begin{array}{c}1.004 \\
(0.049)\end{array}$ & $* * *$ & & $* * *$ & $* * *$ & $* * *$ & *** & $* * *$ & $* * *$ & *** \\
\hline 3 & $\begin{array}{l}\text { Striking against } \\
\text { fixed or stationary } \\
\text { object }\end{array}$ & $\begin{array}{c}0.409 \\
(0.038)\end{array}$ & ns & $* * *$ & & $* * *$ & $* * *$ & *** & $* * *$ & $* * *$ & *** \\
\hline 4 & $\begin{array}{l}\text { Striking against } \\
\text { or Struck by } \\
\text { moving object }\end{array}$ & $\begin{array}{c}0.683 \\
(0.142)\end{array}$ & $* * *$ & $* * *$ & $* * *$ & & $* * *$ & ns & $* * *$ & $* * *$ & ns \\
\hline
\end{tabular}


Table 4. Cont.

\begin{tabular}{|c|c|c|c|c|c|c|c|c|c|c|c|}
\hline & \multicolumn{11}{|c|}{ Accidents Type $(\mathrm{F}=87.566, \mathrm{p}<0.001)$} \\
\hline & Accident Type & $\begin{array}{l}\text { Mean } \\
(\mathrm{SD} \pm)\end{array}$ & 1 & 2 & 3 & 4 & 5 & 6 & 7 & 8 & 9 \\
\hline 5 & $\begin{array}{c}\text { Contact with } \\
\text { electricity or } \\
\text { electric discharge }\end{array}$ & $\begin{array}{c}0.012 \\
(0.006)\end{array}$ & $* * *$ & $* * *$ & $* * *$ & $* * *$ & & $* * *$ & $* *$ & ns & $* * *$ \\
\hline 6 & $\begin{array}{c}\text { Injured while } \\
\text { lifting or carrying }\end{array}$ & $\begin{array}{c}0.682 \\
(0.143)\end{array}$ & $* * *$ & $* * *$ & $* * *$ & ns & $* * *$ & & $* * *$ & $* * *$ & ns \\
\hline 7 & $\begin{array}{c}\text { Trapped in or } \\
\text { between objects }\end{array}$ & $\begin{array}{c}0.169 \\
(0.038)\end{array}$ & $* * *$ & $* * *$ & $* * *$ & $* * *$ & $* *$ & $* * *$ & & ns & $* * *$ \\
\hline 8 & $\begin{array}{c}\text { Struck by falling } \\
\text { object }\end{array}$ & $\begin{array}{c}0.093 \\
(0.019)\end{array}$ & $* * *$ & $* * *$ & $* * *$ & $* * *$ & ns & $* * *$ & ns & & $* * *$ \\
\hline 9 & * Others & $\begin{array}{c}0.659 \\
(0.122)\end{array}$ & $* * *$ & $* * *$ & $* * *$ & ns & $* * *$ & ns & $* * *$ & $* * *$ & \\
\hline
\end{tabular}

Table 5. Result of ANOVA analysis based on mortality rates (MRs).

\begin{tabular}{|c|c|c|c|c|c|c|c|c|c|c|c|}
\hline & \multirow{2}{*}{ Accident Type } & \multicolumn{10}{|c|}{ Accidents Type $(\mathrm{F}=17.423, \mathrm{p}<0.001)$} \\
\hline & & $\begin{array}{l}\text { Mean } \\
(\mathrm{SD} \pm)\end{array}$ & 1 & 2 & 3 & 4 & 5 & 6 & 7 & 8 & 9 \\
\hline 1 & $\begin{array}{l}\text { Fall of person } \\
\text { from height }\end{array}$ & $\begin{array}{l}11.959 \\
(5.094)\end{array}$ & & $* * *$ & $* * *$ & $* * *$ & $* * *$ & $* * *$ & $* * *$ & $* * *$ & $* * *$ \\
\hline 2 & $\begin{array}{l}\text { Slip, trip or fall } \\
\text { on same level }\end{array}$ & 0.0000 & $* * *$ & & ns & ns & * & ns & ns & * & * \\
\hline 3 & $\begin{array}{l}\text { Striking against } \\
\text { fixed or stationary } \\
\text { object }\end{array}$ & $\begin{array}{c}0.201 \\
(0.530)\end{array}$ & $* * *$ & ns & & ns & * & ns & ns & * & * \\
\hline 4 & $\begin{array}{l}\text { Striking against } \\
\text { or Struck by } \\
\text { moving object }\end{array}$ & $\begin{array}{c}2.434 \\
(1.283)\end{array}$ & $* * *$ & ns & ns & & ns & ns & ns & ns & ns \\
\hline 5 & $\begin{array}{c}\text { Contact with } \\
\text { electricity or } \\
\text { electric discharge }\end{array}$ & $\begin{array}{c}2.919 \\
(3.321)\end{array}$ & $* * *$ & * & * & ns & & * & ns & ns & ns \\
\hline 6 & $\begin{array}{c}\text { Injured while } \\
\text { lifting or carrying }\end{array}$ & 0.0000 & $* * *$ & ns & ns & ns & * & & ns & * & * \\
\hline 7 & $\begin{array}{c}\text { Trapped in or } \\
\text { between objects }\end{array}$ & $\begin{array}{c}1.285 \\
(1.024)\end{array}$ & $* * *$ & ns & ns & ns & ns & ns & & ns & ns \\
\hline 8 & $\begin{array}{c}\text { Struck by falling } \\
\text { object }\end{array}$ & $\begin{array}{c}2.879 \\
(2.093)\end{array}$ & $* * *$ & * & * & ns & ns & * & ns & & ns \\
\hline 9 & Others & $\begin{array}{c}3.021 \\
(2.199)\end{array}$ & $* * *$ & * & * & ns & ns & * & ns & ns & \\
\hline
\end{tabular}

* Others: includes all accidents types other than above mentioned in occupational safety and health statics, Labour department of Hong Kong. Results are significant as: ${ }^{*}$ indicates p-value $<0.05$; ${ }^{* *}$ indicates p-value $<0.01$; *** indicates p-value $<0.001$ and " $n s$ " indicates insignificant difference results.

Similarity, to compare the results of accident type with each other correspond to MRs were evaluated with the help of the one-way ANOVA test. Through the post hoc comparison, the results confirm the "fall of person from height" type have higher mean value (mean 11.959) than all other accident type in this study (Table 5). In addition, the "fall of person from height" (mean =11.959, 
$\mathrm{SD}=5.084)$ was the only accident type which manifested the higher significant results $\left.{ }^{* * *}\right)$ with all other accident types during the analysis period. From the analysis of results, it was found that all other accident types have shown the significant effect with "fall of person from height" throughout the analysis period as shown in Table 5 below.

\section{Discussion}

We analyzed several accident types associated with the occupational construction injuries in Hong Kong. To evaluate construction accidents, we have compressively analyzed each accident type which caused an injury or fatality among construction worker from 2011 to 2017.

Tables 4 and 5 indicated the recent trend of occupational accidents in the Hong Kong construction industry concerning accident type. After each year's data collection, with respect to MRs, the results indicated that the accident type "fall of person from height" (mean: MRs $=11.959 / 100,000$ workers) had the highest fatal accidents compared with all other accident types. In addition, Post-hoc comparisons manifested that "fall of person from height" have shown significant result with all other accident types throughout the analysis period. Results also indicated that "Fall of person from height" accounted for $49.29 \%$ of occupational fatalities in Hong Kong throughout the analysis period (2011-2017). On the other hand, with respect to IRs, results of "Slip, trip or fall on same level" have shown a significant result with all other accident types. Moreover, it was the major accident type which caused more occupational injuries during the study period.

The literature highlight that falls are one of the leading causes of all accidents injuries and deaths around the world [31]. Moreover, according to the Occupational Safety and Health Administration (OSHA), "fall from height" is the leading cause of fatality in the construction industry [32]. Similarly, falls or slips were the two main accident types among Iranian construction workers (47.2\%) [33]. Another study Choi et al. [24] indicated that "fall from a higher level" and "struck by" had the higher fatal occupational injuries in China, South Korea and the United States. Another study of Gürcanli and Müngen [34] indicated that falls was also the leading cause of occupational injuries among the Turkish construction workers. Research indicated that falls from height still persistently are the highest construction accident type (serious injuries: $48 \%$ and fatalities: $30 \%$ ) comparing with all other accident types [10,35]. Moreover, falls responsible for $36.9 \%$ of occupational fatalities in the U.S. [36,37], $12 \%$ in Australia and 31\% in the United Kingdom in 2013.

Moreover, 2017 reports indicated that mortality rates (MRs) among Hong Kong construction workers (18.54) and in the U.S. (9.5) [38] was much higher than that in all industries (where MRs are 4.5 in Hong Kong and 3.3 in the U.S.). In the Hong Kong construction industry, both average MRs (24.3) and average fatal accidents ( $78 \%$ ) were consistently higher than all other industries. In addition, the MRs of Hong Kong construction workers found to be much higher as compared to MRs of U.S. construction workers in 2017. The possible reason for higher MRs in Hong Kong construction workers could be due to the higher number of temporary and older construction workers, severe working conditions and poor attitude construction safety attitude of higher management team in construction industry. These above reasons may cause difficulty in the constructing high-rise building in difficult areas.

\section{Future Perspectives}

This section gives an overview of future implementation of SMS system to enhance safety in the Hong Kong construction industry. Also, the potential benefits of new and advanced technologies were mentioned below. 


\subsection{Future Hong Kong Safety Management System(SMS)}

Even though the safety management system (SMS) was implemented in 1991 in Hong Kong's construction industry to reduce accidents as well as to enhance the safe environment at the site [39]. But the result of Table 2 indicated that the accident rate is still consistent among construction workers in Hong Kong. Several researcher's studies [40-42] indicated that there is a lack of successful implementation of SMS in the Hong Kong construction industry. Barriers in SMS implementation includes poor leadership and project management with respect to lacking resources, lack of continuous improvement in term of safety, and competency profile with respect to "poor safety attitude by project team". In addition, tight work schedule, lack of specific legal framework on incidence rate, training criteria, lack of independent safety audit etc. [40]. Therefore, it is necessary to successfully implement SMS in the Hong Kong construction industry. In particular, the major factors which need to be included in SMS are the competency of project personnel, a safer environment and commitment of the senior safety team at the site. In addition, the safety audit by an independent body (no influence with the contractor) on a regular basis could be introduced in Hong Kong's construction in the industry. Besides, an effective life cycle process need to include which contain all the stages i.e. design, planning, construction, repair and maintenance and end life. Through this, an effective framework could be developed which could find the reasons of accident occurrence and help to mitigate it through the difference constriction phases.

\subsection{Advance Technologies for Safety Enhancement}

Tables 4 and 5 results indicated the majority of fatal accidents occurred because of fall of person from height or slip, trip or fall on the same level. The adoption of advanced technologies could reduce the occurrence of the accident in the construction industry. The adaptation of advanced technologies such as sensor-based technologies, robotics, and automation could also enhance safety in the construction industry $[43,44]$. These advanced technologies could promote safety and reduce fatal accidents in Hong Kong construction industry.

Sensor-based technologies are very useful in collecting location data of an object with greater improvement in performance which can serve as a strong pillar for the modern safety construction management [45-48]. Sensor-based technologies include the location-based sensor, vision-based sensors, and wireless sensors, etc. [49,50]. The intelligence of the sensor-based technologies (Global positioning system (GPS), Radio frequency identification (RFID), Ultra-wideband (UWB)) helps interactive platform which can significantly improve the construction worker's safety at the site [51]. The construction of the taller building is common in Hong Kong construction industry, therefore it is necessary to develop an effective and precise framework network of the sensor-based technologies shows in Figure 3. This indicate show sensor technologies could effectively apply at the construction site. Moreover, it also indicates that the sensor can easily locate the hazard location, types and time and gives information in the main office. The officer can easily find the hazard information and report to the site to overcome these issues to avoid accidents at the construction site [52-54]. These technologies will help to identify hazards and provide useful information to overcome it at the construction sites which result in decreasing fatal accidents in the construction industries. 


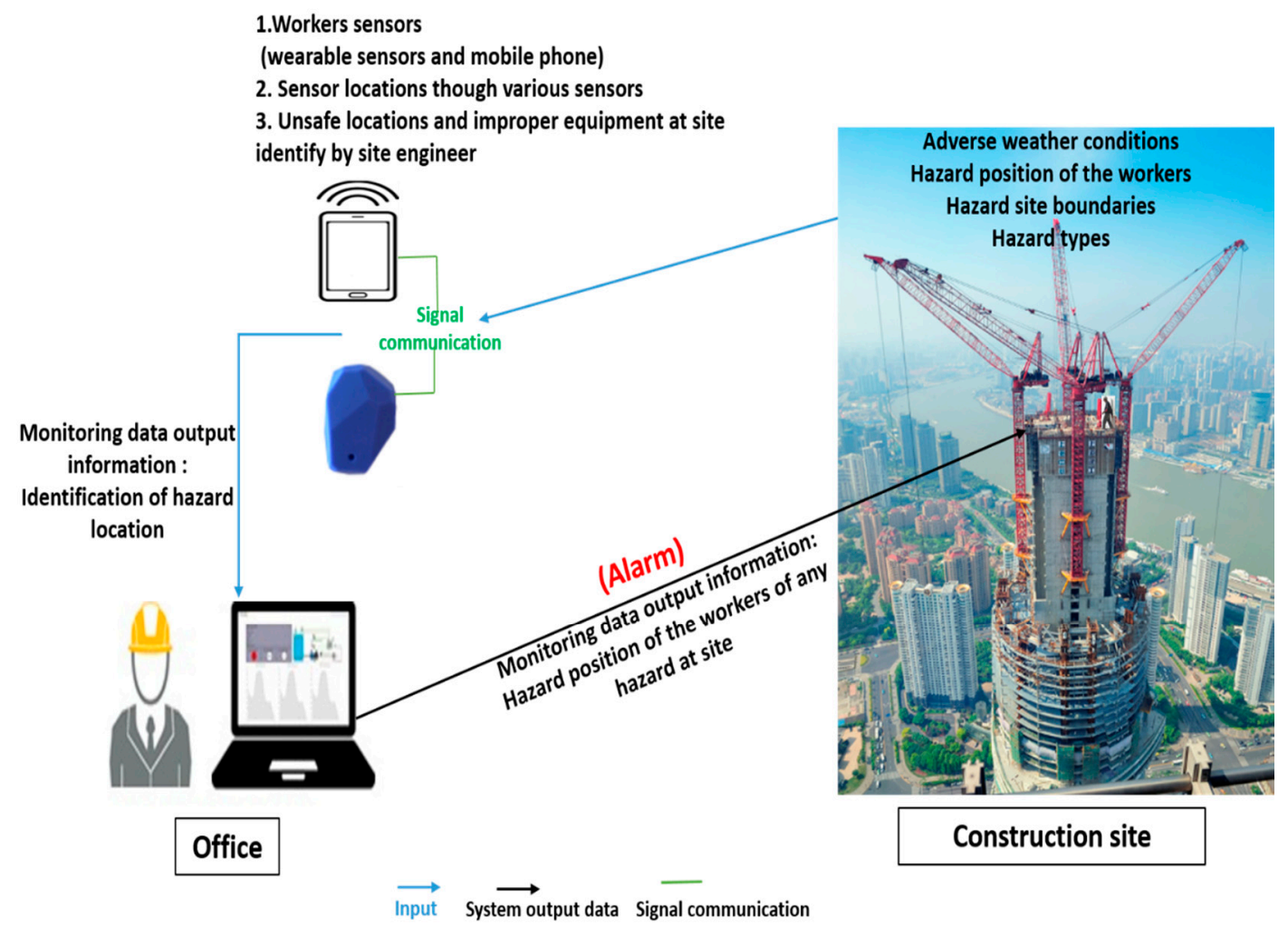

Figure 3. The framework of the sensor based technology at the construction site (authors' illustration).

On the other hand, to reduce accidents related fall of person from height or struck by moving or stationary objects, the adaptation of robotics is an effective safety strategy that is being used recently, Therefore, in Hong Kong construction industry, the robotics in the construction industry could play an important role. Recent studies [55-58] indicated that the robotic can do a number of different forms of work in the construction industry including excavation, demolition buildings, tunnel inspection and constructing walls, etc. as shown in Figure 4. Therefore, to reduce fall-related accidents, robotics could apply in most dangerous places so that we can reduce the fatalities in the construction industry around the world. However, this is a challenging task and requires huge effort to enhance human-robotics interaction [59]. In addition, there is huge research work is required to the adaptation of robotics in the construction industry in the near future.

Lastly, for the development of new innovative SMS for the Hong Kong construction industry, there is a high need for an effective communication system between the workers at the site. Lack of information and communications between the construction workers was found to be the main reasons for accidents at the site [60-63]. This causes a huge risk for the worker's life at the site. A study of Zhang [64] indicated that an effective information management system could reduce accidents at the construction site. Through the use of building information modeling (BIM) at the construction site, the danger zones could be identified and marked for safety at the construction site. Moreover, a study of Wetzel [65] proved that the adaptation of BIM in maintenance works could enhance safety at the workplace. The inclusion of effective information management for worker's communication is necessary and it will not only help effective communication but also enhance the safety in the construction industry. 


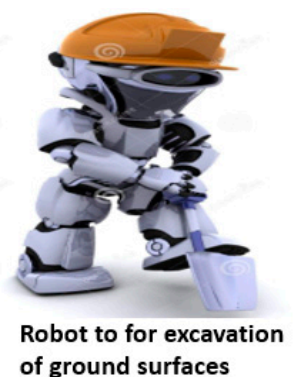
of ground surfaces

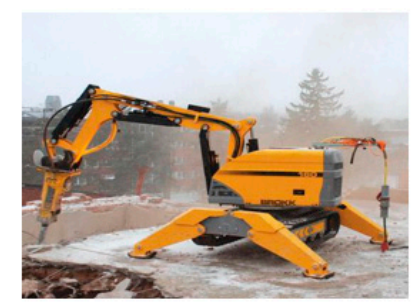

Robotics also can help for demolition of old building at dangers locations

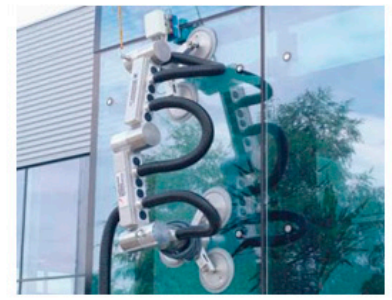

Robotics helps to install the mirror widows at higher elevations
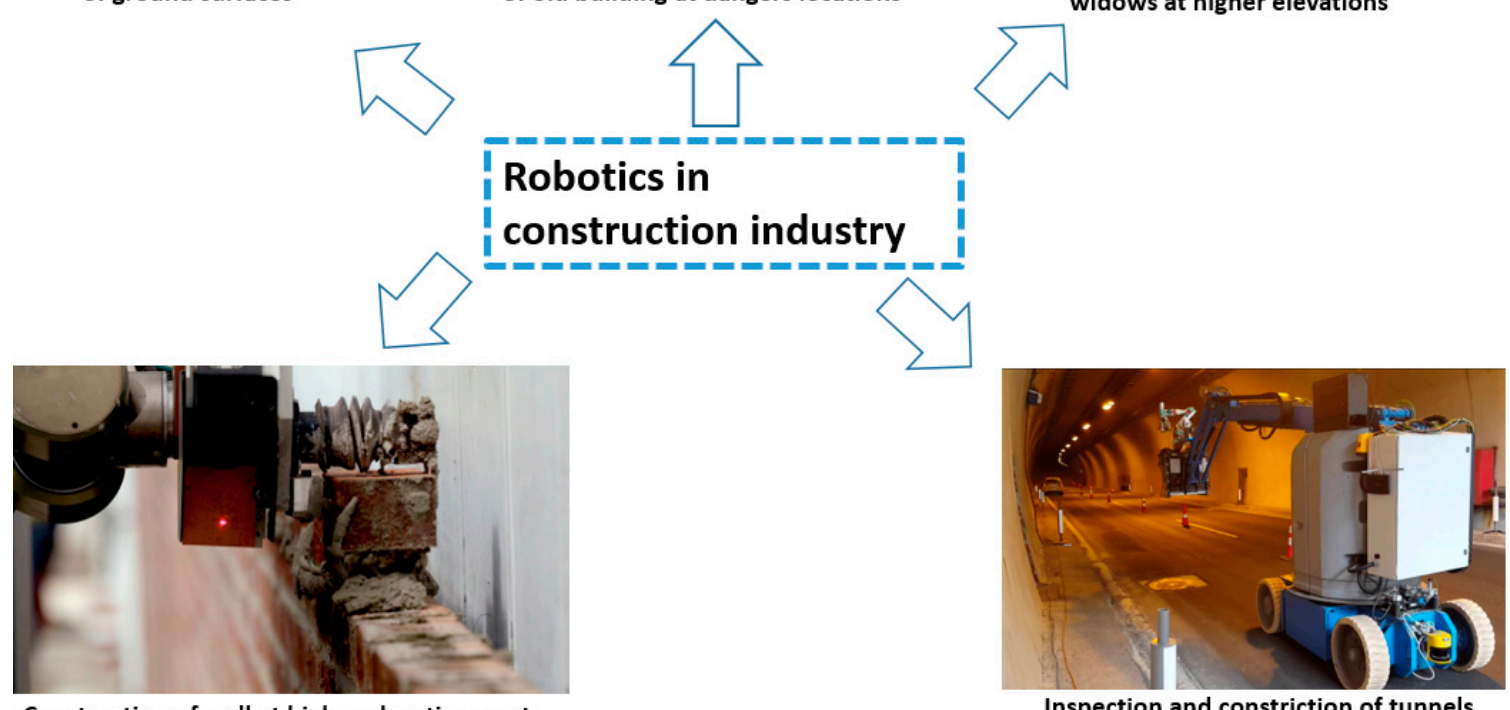

Construction of wall at higher elevation or at dangerous locations

Figure 4. Potential contributions of robotics in the construction industry which helps to reduce fatal accidents.

\section{Conclusions and Limitations}

This study indicates the trend analysis of the occupational injuries among the Hong Kong's construction workers from 2011 to 2017 with the help of incidence and mortality rates. An ANOVA test was performed to compare the relationship of each type of accidents with each other for incidence and mortality rates. The result confirms that the "fall of person from height" and "strip, trip or fall on same level" were the prominent accident types for occupational injuries throughout the analysis period. In addition, as in other countries, "fall of person from height" was one of the greater causes of construction fatal accidents among the construction workers. Furthermore, this study suggested the implementation of new integrating sensor technologies for various benefits at the construction site. Moreover, there is a need to combine the sensor technologies with BIM to establish a new method to find the hard location within the construction site and provide the necessary steps to overcome fatal accidents in the construction industry.

Limitations of this study include: (1) as the source of this study includes the fatal incidence of victims who were absent more than 4 connective days at the construction site. However, the victims who received medical care for less than 4 days were not included in the fatalities. (2) Moreover, the severities of injury, as well as the loss of human body such as hand, finger, foot etc., were not included in this study. (3) Besides, there is a lack of data regarding construction occupational accidents which is not reported to Labour Department of Hong Kong. Other factors such as the incidence rate with respect to construction type are still lacking and significantly affect the occupation injuries in real conditions. Therefore, there is a need for in-depth research for the aforementioned factors which ultimately help to establish effective network to reduce construction fatalities accidents around the world. 
Author Contributions: M.S. and M.R. Conceptualized the study; M.S. collected and analyzed the data; M.S. prepared and wrote the original draft, M.R.; read and revised the paper critically.

Conflicts of Interest: The authors declare no conflict of interest.

\section{References}

1. United Nations, Department of Economic and Social Affairs, Population Division. World Population Prospects: The 2017 Revision, Key Findings and Advance Tables. Working Paper No. ESA/P/WP/248.2017. Available online: https://esa.un.org/unpd/wpp/Publications/Files/WPP2017_KeyFindings.pdf (accessed on 10 April 2019).

2. Bongaarts, J. Human population growth and the demographic transition. Philos. Trans. R. Soc. B Biol. Sci. 2009, 364, 2985-2990. [CrossRef] [PubMed]

3. Akang, E.E.U.; Kuti, M.A.O.; Osunkoya, A.O.; Komolafe, E.O.; Malomo, A.O.; Shokunbi, M.T.; Amutta, S.B. Pattern of fatal head injuries in Ibadan - A 10 year review. Med. Sci. Law 2002, 42, 160-166. [CrossRef] [PubMed]

4. Feng, Y.; Zhang, S.; Wu, P. Factors influencing workplace accident costs of building projects. Saf. Sci. 2015, 72, 97-104. [CrossRef]

5. Mohseni, P.H.; Farshad, A.A.; Mirkazemi, R.; Orak, R.J. Assessment of the living and workplace health and safety conditions of site-resident construction workers in Tehran, Iran. Int. J. Occup. Saf. Ergon. 2015, 21, 568-573. [CrossRef] [PubMed]

6. Nadhim, E.A.; Hon, C.; Xia, B.; Stewart, I.; Fang, D. Falls from height in the construction industry: A critical review of the scientific literature. Int. J. Environ. Res. Public Health 2016, 13, 638. [CrossRef] [PubMed]

7. Tao, L.; Wu, C.; Chiang, Y.-H.; Wong, F.K.-W.; Liang, S. Generational Perceptions of Freedom-Related Work Values: Hong Kong's Implementation of a No-Saturday-Site-Work Policy in Construction. J. Constr. Eng. Manag. 2017, 143, 06017002. [CrossRef]

8. Sunindijo, R.Y.; Zou, P.X.W. Political Skill for Developing Construction Safety Climate. J. Constr. Eng. Manag. 2011, 138, 605-612. [CrossRef]

9. Kines, P.; Mikkelsen, K.L. Effects of Firm Size on Risks and Reporting of Elevation Fall Injury in Construction Trades. J. Occup. Environ. Med. 2003, 45, 1074-1078. [CrossRef]

10. Hanapi, N.M.; Kamal, M.M.M.; Ismail, M.I.; Abdullah, I.A.P. Identifying Root Causes and Mitigation Measures of Construction Fall Accidents. Gading Bus. Manag. J. 2013, 17, 65-79.

11. Bureau of Labor Statistics, U.S. 2017. Available online: https:/www.bls.gov/opub/mlr/2017/home.htm (accessed on 5 March 2019).

12. Labour Department. Occupational Safety and Health Statistics: Bulletin Issue No. 18. 2018. Available online: https://www.labour.gov.hk/eng/osh/content10.htm (accessed on 20 Febraury 2019).

13. Health and Safety Executive, U.K. Fatal Injuries Arising from Accidents at Work in Great Britain: Headline Results 2017/18 [Online]. 2017. Available online: http://www.hse.gov.uk/statistics/fatals.htm (accessed on 20 December 2018).

14. JISHA Japan Industrial Safety and Health Association. OSH Statistics in Japan. 2017. Available online: https://www.jisha.or.jp/english/statistics/accidents_in_detail_2017.html (accessed on 19 December 2018).

15. Fabiano, B.; Currò, F.; Reverberi, A.P.; Pastorino, R. A statistical study on temporary work and occupational accidents: Specific risk factors and risk management strategies. Saf. Sci. 2008, 46, 535-544. [CrossRef]

16. Macedo, A.C.; Silva, I.L. Analysis of occupational accidents in Portugal between 1992 and 2001. Saf. Sci. 2005, 43, 269-286. [CrossRef]

17. Jackson, S.A.; Loomis, D. Fatal occupational injuries in the North Carolina construction industry, 1978-1994. Appl. Occup. Environ. Hyg. 2002, 17, 27-33. [CrossRef] [PubMed]

18. Jo, B.W.; Lee, Y.S.; Kim, J.H.; Khan, R.M.A. Trend analysis of construction industrial accidents in Korea from 2011 to 2015. Sustainability 2017, 9, 1297. [CrossRef]

19. Workplace Safety and Health Institute. Global Estimates of Occupational Accidents and Work-Related Illnesses. 2017. Available online: http://www.icohweb.org/site/images/news/pdf/Report\%20Global\% 20Estimates\%20of\%20Occupational\%20Accidents\%20and\%20Work-related\%20Illnesses\%202017\%20rev1. pdf (accessed on 20 November 2018). 
20. Hamid, A.R.A.; Majid, M.Z.A.; Singh, B. Causes of accidents at construction sites. Malaysian J. Civ. Eng. 2008, 20. [CrossRef]

21. Dejus, T. Accidents On Construction Sites And Their Reasons. Constr. Technol. Manag. 2012, 20. [CrossRef]

22. Duff, A.R.; Everett, J.G.; Suraji, A.; Haslam, R.; Gibb, A.; Abdelhamid, T.S.; Hastings, S.; Hide, S. Identifying Root Causes of Construction Accidents. J. Constr. Eng. Manag. 2002, 126, 52-60.

23. Chan, D.W.M.; Yam, M.C.H.; Chan, A.P.C.; Kwok, A.W.K.; Wong, F.K.W.; Cheung, E.; Lam, E.W.M. Work at Height Fatalities in the Repair, Maintenance, Alteration, and Addition Works. J. Constr. Eng. Manag. 2008, 134, 527-535. [CrossRef]

24. Choi, S.D.; Guo, L.; Kim, J.; Xiong, S. Comparison of fatal occupational injuries in construction industry in the United States, South Korea, and China. Int. J. Ind. Ergon. 2019, 71, 64-74. [CrossRef]

25. Chan, D.W.M.; Choi, T.N.Y. Critical analysis of the application of the Safe Working Cycle (SWC): Interview findings from Hong Kong. J. Facil. Manag. 2015, 13, 244-265. [CrossRef]

26. Chan, D.W.M.; Chan, A.P.C.; Choi, T.N.Y. An empirical survey of the benefits of implementing pay for safety scheme (PFSS) in the Hong Kong construction industry. J. Safety Res. 2010, 41, 433-443. [CrossRef]

27. Yu, S.C.; Hunt, B. Safety management systems in Hong Kong: is there anything wrong with the implementation? Manag. Audit. J. 2002, 17, 588-592. [CrossRef]

28. Chiang, Y.-H.; Wong, F.K.-W.; Liang, S. Fatal Construction Accidents in Hong Kong. J. Constr. Eng. Manag. 2017, 144, 04017121. [CrossRef]

29. Chan, A.P.C.; Hon, C.K.H. Safety of Repair, Maintenance, Minor Alteration, and Addition (RMAA) Works: A New Focus of Construction Safety; Routledge: Abingdon, UK, 2016; ISBN 9781315677378.

30. Labour Department of Hong Kong Occupational Safety and Health Branch. Available online: https: //www.labour.gov.hk/eng/osh/content.htm (accessed on 20 November 2018).

31. World Health Organization. Falls: Fact sheet. [WWW Document]. WHO Accessed, Media Cent. 2018. Available online: https:/www.who.int/news-room/fact-sheets/detail/falls (accessed on 10 March 2019).

32. OSHA Training Institute. Construction Focus Four: Fall Hazards. 2011. Available online: http://oshaedne. com/files/ConstrFocusFourIntroduction_April2011.pdf (accessed on 05 April 2019).

33. Amiri, M.; Ardeshir, A.; Fazel Zarandi, M.H. Risk-based Analysis of Construction Accidents in Iran During 2007-2011-Meta Analyze Study. Iran. J. Public Health 2014, 43, 507. [PubMed]

34. GÜRCANLI, G.E.; MÜNGEN, U. Analysis of Construction Accidents in Turkey and Responsible Parties. Ind. Health 2013, 51, 581-595. [CrossRef]

35. Hu, K.; Rahmandad, H.; Smith-Jackson, T.; Winchester, W. Factors influencing the risk of falls in the constructionindustry: A review of the evidence. Constr. Manag. Econ. 2011, 29, 397-416. [CrossRef]

36. BLS Fatal Occupational Injuries by Industry and Event or Exposure. Available online: https://www.bls.gov/ news.release/pdf/cfoi.pdf (accessed on 10 March 2019).

37. HSE Health and Safety in Construction Sector in Great Britain 2014/15. Available online: file://C:/Users/shafiq/ Downloads/HSE_HealthSafetyStatistics_201415_ConstructionBreakdown.pdf (accessed on 16 December 2018).

38. Bureau of Labor Statistics (BLS) April 2017 Monthly Labor Review - an Analysis of Fatal Occupational Injuries at Road Construction Site, 2016-2017. Available online: https://www.bls.gov/news.release/cfoi.t04.htm (accessed on 3 January 2019).

39. Labour Department. Code of Practice on Safety Management. Hong Kong: Occupational Safety and Health Branch, Labour Department. 2002. Available online: https://www.labour.gov.hk/eng/public/os/manage.pdf (accessed on 18 February 2019).

40. Yiu, N.S.N.; Sze, N.N.; Chan, D.W.M. Implementation of safety management systems in Hong Kong construction industry-A safety practitioner's perspective. J. Safety Res. 2018, 64, 1-9. [CrossRef]

41. Yiu, N.S.N.; Chan, D.W.M.; Shan, M.; Sze, N.N. Implementation of safety management system in managing construction projects: Benefits and obstacles. Saf. Sci. 2019, 117, 23-32. [CrossRef]

42. Choudhry, R.M.; Fang, D.; Ahmed, S.M. Safety Management in Construction: Best Practices in Hong Kong. J. Prof. Issues Eng. Educ. Pract. 2007, 134, 20-32. [CrossRef]

43. Chen, Q.; García de Soto, B.; Adey, B.T. Construction automation: Research areas, industry concerns and suggestions for advancement. Autom. Constr. 2018, 94, 22-38. [CrossRef]

44. Lee, W.H.; Tse, K.H.D.; Ma, W.K.P. Applied Technologies in Minimizing Accidents in Construction Industry. Procedia Environ. Sci. 2016, 36, 54-56. [CrossRef] 
45. Lu, M.; Chen, W.; Shen, X.; Lam, H.C.; Liu, J. Positioning and tracking construction vehicles in highly dense urban areas and building construction sites. Autom. Constr. 2007, 16, 647-656. [CrossRef]

46. Gu, Y.; Lo, A.; Niemegeers, I. A survey of indoor positioning systems for wireless personal networks. IEEE Commun. Surv. Tutorials 2009, 11, 2009. [CrossRef]

47. Maalek, R.; Sadeghpour, F. Accuracy assessment of Ultra-Wide Band technology in tracking static resources in indoor construction scenarios. Autom. Constr. 2013, 30, 170-183. [CrossRef]

48. Khoury, H.M.; Kamat, V.R. Evaluation of position tracking technologies for user localization in indoor construction environments. Autom. Constr. 2009, 18, 444-457. [CrossRef]

49. Lee, W.; Lin, K.Y.; Seto, E.; Migliaccio, G.C. Wearable sensors for monitoring on-duty and off-duty worker physiological status and activities in construction. Autom. Constr. 2017, 83, 341-353. [CrossRef]

50. Cheng, T.; Teizer, J. Real-time resource location data collection and visualization technology for construction safety and activity monitoring applications. Autom. Constr. 2013, 34, 3-15. [CrossRef]

51. Awolusi, I.; Marks, E.; Hallowell, M. Wearable technology for personalized construction safety monitoring and trending: Review of applicable devices. Autom. Constr. 2018, 85, 96-106. [CrossRef]

52. Guo, H.; Yu, Y.; Skitmore, M. Visualization technology-based construction safety management: A review. Autom. Constr. 2017, 73, 135-144. [CrossRef]

53. Luo, H.; Xiong, C.; Fang, W.; Love, P.E.D.; Zhang, B.; Ouyang, X. Convolutional neural networks: Computer vision-based workforce activity assessment in construction. Autom. Constr. 2018, 94, 282-289. [CrossRef]

54. Feng, C.; Kamat, V.R.; Cai, H. Camera marker networks for articulated machine pose estimation. Autom. Constr. 2018, 96, 148-160. [CrossRef]

55. Helwa, M.K.; Schoellig, A.P. On the construction of safe controllable regions for affine systems with applications to robotics. Automatica 2018, 98, 323-330. [CrossRef]

56. Chen, J.; Wang, J.; Xiao, Q.; Chen, C. A Multi-Robot Task Allocation Method Based on Multi-Objective Optimization. In Proceedings of the 15th International Conference on Control, Automation, Robotics and Vision, ICARCV 2018, Singapore, 18-21 November 2018; Institute of Electrical and Electronics Engineers Inc.: Zhaoqing University, School of Computer Science and Software, Zhaoqing, Guangdong, China, 2018; pp. 1868-1873.

57. Menendez, E.; Victores, J.G.; Montero, R.; Balaguer, C. Autonomous Robotic System with Tunnel Inspection Tool Positioning. In Proceedings of the 34th International Symposium on Automation and Robotics in Construction (ISARC), Taipei, Taiwan, 28 June-1 July 2017; Vilnius Gediminas Technical University: Vilnius, Lithuania, 2017.

58. King, N.; Bechthold, M.; Kane, A.; Michalatos, P. Robotic tile placement: Tools, techniques and feasibility. Autom. Constr. 2014, 39, 161-166. [CrossRef]

59. You, S.; Kim, J.-H.; Lee, S.; Kamat, V.; Robert, L.P., Jr. Enhancing perceived safety in human-robot collaborative construction using immersive virtual environments. Autom. Constr. 2018, 96, 161-170. [CrossRef]

60. Hide, S.; Atkinson, S.; Pavitt, T.C.; Haslam, R.; Gibb, A.G.; Gyi, D.E. Causal Factors in Construction Accidents; HSE research report 156; Health and Safety Executive: Bootle, UK, 2003; ISBN 0717627497.

61. Sawacha, E.; Naoum, S.; Fong, D. Factors affecting safety performance on construction sites. Int. J. Proj. Manag. 1999, 17, 309-315. [CrossRef]

62. Khosravi, Y.; Asilian-Mahabadi, H.; Hajizadeh, E.; Hassanzadeh-Rangi, N.; Bastani, H.; Behzadan, A.H. Factors influencing unsafe behaviors and accidents on construction sites: A review. Int. J. Occup. Saf. Ergon. 2014, 20, 111-125. [CrossRef]

63. Zou, Y.; Kiviniemi, A.; Jones, S.W. A review of risk management through BIM and BIM-related technologies. Saf. Sci. 2017, 97, 88-98. [CrossRef] 
64. Zhang, S.; Teizer, J.; Lee, J.K.; Eastman, C.M.; Venugopal, M. Building Information Modeling (BIM) and Safety: Automatic Safety Checking of Construction Models and Schedules. Autom. Constr. 2013, 29, $183-195$. [CrossRef]

65. Wetzel, E.M.; Thabet, W.Y. The use of a BIM-based framework to support safe facility management processes. Autom. Constr. 2015, 60, 12-24. [CrossRef] article distributed under the terms and conditions of the Creative Commons Attribution (CC BY) license (http://creativecommons.org/licenses/by/4.0/). 